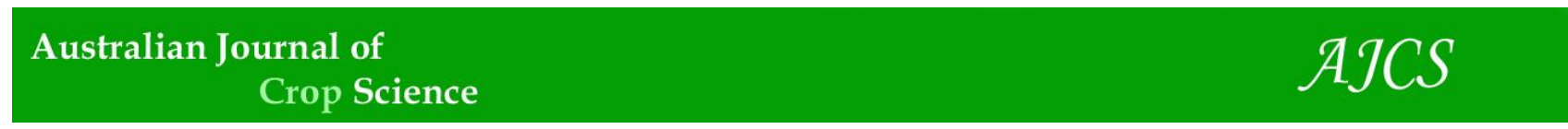

AJCS 13(04):616-621 (2019)

ISSN:1835-2707

doi: 10.21475/ajcs.19.13.04.p1648

\title{
Response of spring wheat genotypes to organic farming systems in low-fertility soil
}

\author{
Nasser S. AL-Ghumaiz*, Mohamed I Motawei, Abdulrahman A Al-Soqeer \\ Department of Plant Production and Protection-College of Agriculture and Veterinary Medicine, Qassim University, \\ Buridah, Qassim, 51452, The Kingdom of Saudi Arabia
}

*Corresponding author: nghumaiz@gmail.com

\section{Abstract}

Low-fertility soil is considered a major challenge for growing wheat (Triticum aestivum) in organic systems. The objective of this study was to identify spring wheat genotype(s) adapted to growing in organic systems with low-fertility soil compared with conventional systems in the central region of Saudi Arabia. Organic and conventional trials were established during the 2010, 2011 and 2012 growing seasons in the arid environment of central region of Saudi Arabia. Both trails were seeded in a sandy loam soil. Eight bread wheat genotypes were evaluated for the following parameters: grain and straw yields, grain-filling rate (GFR), days to heading (DTH), days to maturity (DTM), number of kernels per spike and 1000-kernel weight. The experiment was a randomized complete block design (RCBD) with four replications. The findings showed that there were significant differences in grain and straw yields between the two systems and among genotypes. The Egyptian genotypes 'Sids 12' and Early-line produced the highest grain yields $\left(7.8\right.$ tons $\mathrm{ha}^{-1}$ ) in the conventional system, whereas in the organic system, Yocora Rojo (control genotype) and Early-line produced the highest yields (5.8 and 5.9 tons ha $^{-1}$, respectively). Grain and straw yields were higher in 2011 and 2012 growing seasons compared to 2010. Early-line and ICARDA genotypes (IC8 and IC17) had the highest grain-filling rate, whereas the Australian genotypes (P5 and P3) and the local genotype 'Sama' had the lowest grain-filling rate. The genotype Early-line had the shortest time to heading and maturity in both systems. Therefore, Early-line and Yocora Rojo are promising bread wheat genotypes for organic production systems in low-fertility soil.

Keywords: Wheat genotypes, grain-filling rate, grain yield, conventional system, organic system, low fertility soil.

\section{Introduction}

Organic agriculture is dependent on organic sources of nutrients. However, low-fertility soil is considered a major challenge in growing crops organically. Several studies have found that organic systems had significantly lower crop yield compared to conventional farming systems (Stanhill 1990; Ryan et al., 2004). Gevrekk and Atasoy (2012) suggested that wheat yield reduction in organic systems was primarily due to reduced kernel number spike ${ }^{-1}$ and 1000 -grain weight. Lammerts van Buerena et al. (2011) reported that conventional bred wheat varieties do not have important traits required for organic and low-input production conditions. Other studies have shown that there were differences in responses among wheat varieties in terms of crop performance and quality attributes in organic farming systems and that traditional varieties responded better in organic systems (Nass et al., 2003; Carr et al., 2006; Mason et al., 2007; Murphy et al., 2007). However, it is possible to identify genotypes suitable for conventional farming management, in which they have high yield and quality characteristics under organic farming conditions (lannucci and Codianni, 2016). Nelson et al. (2011) found that grain protein content tended to increase with increasing nitrogen fertilizer application in conventional systems. Mäder et al. (2007) found that wheat grain from conventional farming systems had a $6 \%$ higher protein content than that from organic farming systems. However, there were no significant differences between organic wheat and conventional wheat in terms of the contents of macro and micro elements $(P, K$, $\mathrm{Ca}, \mathrm{Zn}, \mathrm{Mo}$, and $\mathrm{Co}$ ), flour milling properties, starch quality, and rheological properties of the dough. The organic production area in Saudi Arabia is about 121 thousand hectares (Ministry of Environment, Water and Agriculture 2015) and during recent years, there has been an increase in the organic production area in Saudi Arabia which results in an increase in consumption of organic food. In the central region of Saudi Arabia, soils are primarily sandy and contain low levels of organic matter $(0.4 \%)$ with a $\mathrm{pH}$ value of 8.1 and high salinity. Thus, growing wheat organically in such areas may be a major challenge for wheat producers. The promising results from our previous paper (Al-Ghumaiz 2014) encouraged us to extend our work to further investigate wheat varieties for organic systems. Therefore, the aim of this study was to identify spring wheat genotype(s) that have adapted to organic systems compared to conventional farming systems in Saudi Arabia.

Results

\section{Grain and straw yields}

Significant differences were found in grain yield between the conventional and organic systems with higher wheat yields in the conventional system (6.9 versus $4.9 \mathrm{t}$ ha) (Table 4 ). 
Table 1. Soil chemical and physical characteristics of the two experiment sites.

\begin{tabular}{|c|c|c|c|c|c|c|c|c|c|}
\hline \multirow{2}{*}{ Trial Type } & \multicolumn{6}{|c|}{ Chemical analysis } & \multicolumn{3}{|c|}{ Physical analysis (\%) } \\
\hline & $\mathrm{K}(\mathrm{ppm})$ & $\mathrm{P}(\mathrm{ppm})$ & $\mathrm{N}(\mathrm{ppm})$ & OM & $\mathrm{pH}$ & $\mathrm{EC}(\mathrm{ds} / \mathrm{m})$ & Clay & Silt & Sand \\
\hline Conventional site & 34 & 33.1 & 15.7 & 0.4 & 8.1 & 5.3 & 0.4 & 4.2 & 94.9 \\
\hline Organic site & 36.5 & 22.1 & 52.5 & 1.4 & 7.9 & 1.9 & 0.9 & 4.5 & 94.5 \\
\hline
\end{tabular}

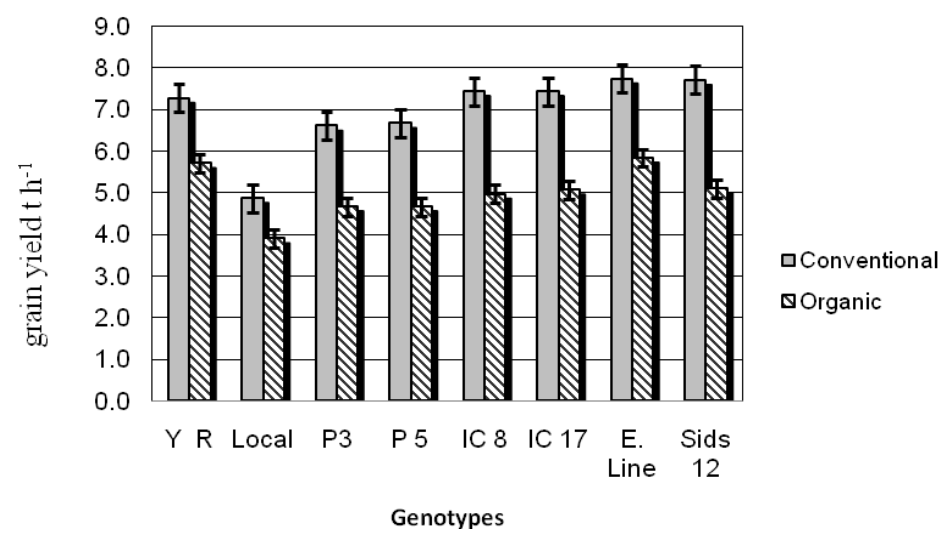

Fig 1. Effect of agriculture systems and wheat genotypes on grain yield.

Table 2. Average daily minimum and maximum air temperatures $\left({ }^{\circ} \mathrm{C}\right)$; relative humidity $(\mathrm{RH} \%$ ), and precipitation ( $\mathrm{mm} / \mathrm{month}$ ) during 2010, 2011 and 2012 growing seasons*

\begin{tabular}{|c|c|c|c|c|c|c|c|c|c|c|c|c|}
\hline \multirow{3}{*}{ Month } & \multicolumn{4}{|c|}{2010 season } & \multicolumn{4}{|c|}{2011 season } & \multicolumn{4}{|c|}{2012 season } \\
\hline & \multicolumn{2}{|c|}{ Temperature ${ }^{\circ} \mathrm{C}$} & \multirow{2}{*}{$\begin{array}{l}\mathrm{RH} \\
\%\end{array}$} & \multirow{2}{*}{ Precipitation } & \multicolumn{2}{|c|}{ Temperature ${ }^{\circ} \mathrm{C}$} & \multirow{2}{*}{$\begin{array}{l}\mathrm{RH} \\
\%\end{array}$} & \multirow{2}{*}{ Precipitation } & \multicolumn{2}{|c|}{ Temperature ${ }^{\circ} \mathrm{C}$} & \multirow{2}{*}{$\begin{array}{l}\mathrm{RH} \\
\% \\
\end{array}$} & \multirow{2}{*}{ Precipitation } \\
\hline & Mane & Extreme & & & Mane & Extreme & & & Mean & Extreme & & \\
\hline Jan. & 16 & $3-31$ & 58 & 2.7 & 14.6 & $2-26$ & 67.8 & 34.3 & 14.2 & $0-28$ & 52.0 & 0.0 \\
\hline Feb. & 19 & $0-34$ & 46 & 1 & 17.7 & $5-32$ & 50.2 & 0.0 & 16.4 & $3-33$ & 47.0 & 7.7 \\
\hline Mar & 22 & $8-39$ & 35 & 0 & 19.5 & $4-36$ & 39.1 & 8.7 & 19.0 & $4-37$ & 38.0 & 3.8 \\
\hline Apr & 27 & $13-41$ & 48 & 27.9 & 25.1 & $12-39$ & 45.9 & 46.4 & 26.8 & $14-39$ & 40.0 & 7.1 \\
\hline May & 32 & $17-45$ & 34 & 16.4 & 32.3 & $18-45$ & 29.1 & 2.8 & 33.6 & $20-45$ & 22.0 & 2.2 \\
\hline
\end{tabular}

Source: Presidency of Meteorology \& Environmental Protection-Saudi Arabia.

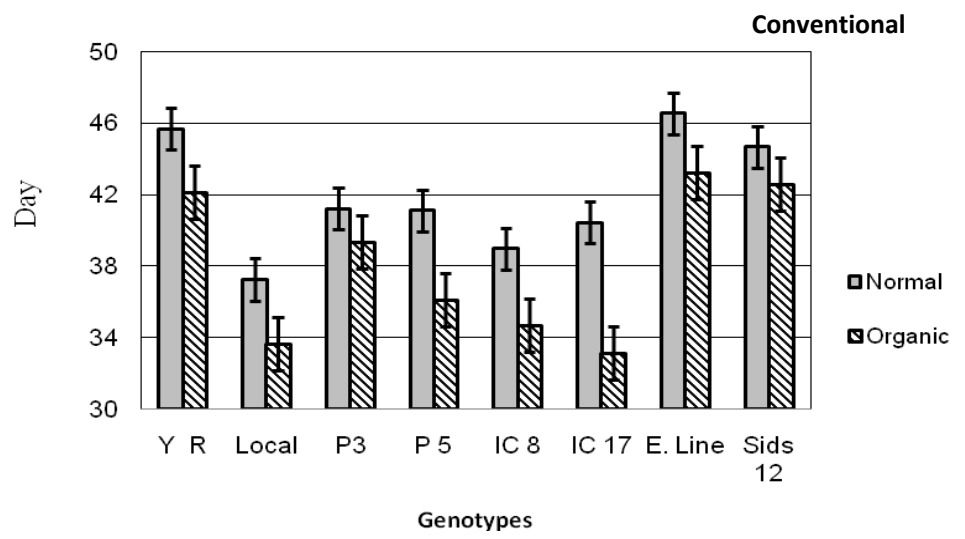

Fig 2. Effect of agriculture systems and wheat genotypes on grain filling period.

Table 3. The eight wheat genotypes investigated in this study.

\begin{tabular}{ll}
\hline Genotype name & Source \\
\hline YR $^{\dagger}$ & USA \\
Local $^{\ddagger}$ & KSA \\
P3 (AUS-030851) & Australia \\
P5 (AUS-030852) & Australia \\
IC8 (Line-2-ICARDA-1 & st RDRN0607) $_{\text {ICARDA }}^{\S}$ \\
IC17 (Line-56 ICARDA-1 & RDRN0607) \\
Early-Line & ICARDA \\
Sids 12 & Egypt \\
\hline
\end{tabular}

${ }^{\dagger}$ Yocora Rojo (YR) commercial genotype commonly grown in Saudi Arabia. ${ }^{\dagger}$ The local genotype is named Sama.

${ }^{5}$ ICARDA: International Center for Agricultural Research in the Dry Areas. 


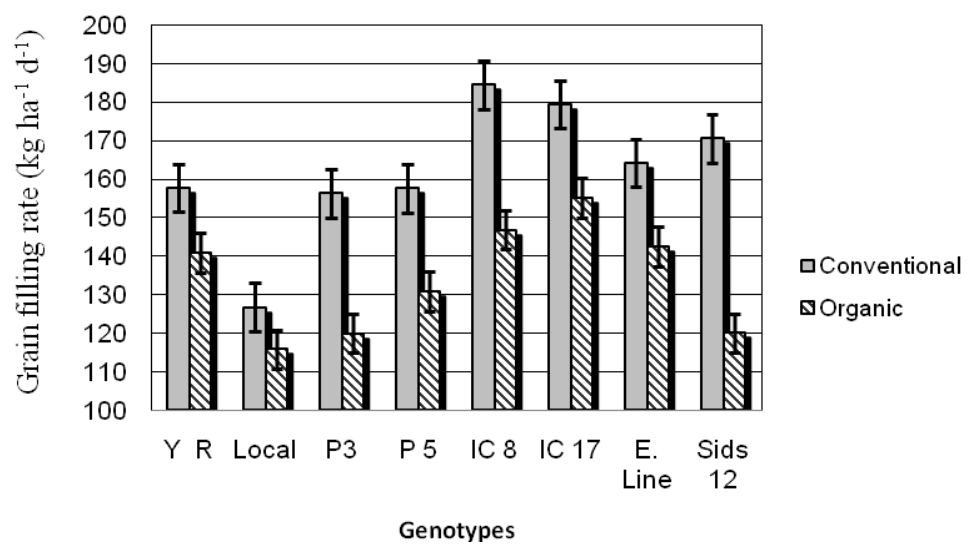

Fig 3. Effect of agriculture systems and wheat genotypes on grain filling rate.

Table 4. The effect of agriculture systems, genotypes and years on days to heading (DTH), days to maturity (DTM), grain-filling period (GFP),, grain-filling rate (GFR), grain yield (GY), straw yield (SY), kernels spike ${ }^{-1}$ and 1000-kernel weight.

\begin{tabular}{|c|c|c|c|c|c|c|c|c|}
\hline Treatment & DTH & $\begin{array}{l}\text { DTM } \\
\text { (Days) }\end{array}$ & $\begin{array}{c}\text { GFP } \\
\text { (Days) }\end{array}$ & $\begin{array}{r}\text { GFR } \\
\left(k g h a^{-1} d^{1}\right)\end{array}$ & $\begin{array}{l}\text { GY } \\
\text { (tons ha }{ }^{-1} \text { ) }\end{array}$ & $\begin{array}{l}\text { SY } \\
\text { (tons ha }{ }^{-1} \text { ) }\end{array}$ & $\begin{array}{l}\text { kernels } \\
\text { spike }^{-1}\end{array}$ & $\begin{array}{l}\text { kernel } \\
\text { weight } \\
\text { (gm) }\end{array}$ \\
\hline \multicolumn{9}{|c|}{ Agriculture Systems (S) } \\
\hline Conventional & $77.9 b$ & $118.8 \mathrm{a}$ & 41.98a & $162.1 a$ & $6.9 a$ & $13.7 a$ & $48.9 a$ & $43.3 \mathrm{a}$ \\
\hline Organic & $82.8 a$ & $120.8 a$ & $38.09 \mathrm{~b}$ & $133.9 b$ & $4.9 \mathrm{~b}$ & $11.7 \mathrm{~b}$ & $47.1 \mathrm{a}$ & $38.6 \mathrm{~b}$ \\
\hline Sig & $* *$ & n.s. & $* *$ & $* *$ & $* *$ & $* *$ & n.s. & $* *$ \\
\hline \multicolumn{9}{|c|}{ Genotype (G) } \\
\hline YR & $72.5 \mathrm{f}$ & $116.4 \mathrm{~d}$ & 43.89ab & $149.3 \mathrm{~b}$ & $6.1 \mathrm{ab}$ & $8.6 \mathrm{bc}$ & $40.9 \mathrm{~b}$ & $46.2 \mathrm{a}$ \\
\hline Local & $91.4 \mathrm{a}$ & $126.8 \mathrm{a}$ & $35.44 d$ & $121.3 \mathrm{c}$ & $4.1 \mathrm{c}$ & $12.2 \mathrm{a}$ & $43.0 \mathrm{~b}$ & $34.4 b$ \\
\hline P3 & $81.0 \mathrm{~d}$ & $121.3 \mathrm{bc}$ & $40.28 b c$ & $138.2 \mathrm{~b}$ & $5.2 \mathrm{~b}$ & $9.9 \mathrm{abc}$ & $44.5 \mathrm{~b}$ & $40.2 \mathrm{ab}$ \\
\hline P5 & $83.4 \mathrm{~cd}$ & $122.1 \mathrm{bc}$ & $38.61 \mathrm{~cd}$ & $144.2 \mathrm{~b}$ & $5.2 \mathrm{~b}$ & $9.9 \mathrm{abc}$ & $43.7 \mathrm{~b}$ & $39.8 \mathrm{ab}$ \\
\hline IC8 & $85.3 \mathrm{bc}$ & $122.2 \mathrm{bc}$ & $36.83 \mathrm{~cd}$ & $165.6 \mathrm{a}$ & $5.6 a b$ & 10.1abc & $54.3 \mathrm{a}$ & 37.4 b \\
\hline IC17 & $86.6 \mathrm{~b}$ & $123.4 \mathrm{ab}$ & $36.78 \mathrm{~cd}$ & $167.2 \mathrm{a}$ & $5.8 \mathrm{ab}$ & $11.0 \mathrm{ab}$ & $54.1 \mathrm{a}$ & $39.6 \mathrm{ab}$ \\
\hline E. Line & $67.1 \mathrm{~g}$ & $112.0 \mathrm{e}$ & $44.89 a$ & $153.4 \mathrm{ab}$ & $6.4 \mathrm{a}$ & $8.4 \mathrm{c}$ & $44.2 \mathrm{~b}$ & $45.1 \mathrm{a}$ \\
\hline Sids 12 & $75.6 \mathrm{e}$ & $119.2 \mathrm{~cd}$ & 43.61ab & $145.3 \mathrm{~b}$ & $6.0 \mathrm{ab}$ & $9.5 \mathrm{bc}$ & 59.5 a & $44.9 \mathrm{a}$ \\
\hline Sig & $* *$ & $* *$ & $* *$ & $* *$ & $* *$ & $* *$ & $* *$ & $* *$ \\
\hline$S \times G$ & n.s & n.s & n.s & n.s & n.s & n.s & n.s & n.s \\
\hline \multicolumn{9}{|c|}{ Years } \\
\hline 2010 & $75.5 b$ & $112.5 \mathrm{c}$ & $37.10 \mathrm{c}$ & $103.3 \mathrm{c}$ & $3.8 \mathrm{c}$ & $7.2 \mathrm{c}$ & $45.8 \mathrm{~b}$ & $34.2 \mathrm{~b}$ \\
\hline 2011 & $82.1 a$ & $122.7 b$ & $40.50 \mathrm{~b}$ & $192.0 \mathrm{a}$ & $7.8 \mathrm{a}$ & $12.7 \mathrm{a}$ & $53.1 \mathrm{a}$ & $43.1 \mathrm{a}$ \\
\hline 2012 & $83.5 a$ & $126.1 \mathrm{a}$ & $42.52 \mathrm{a}$ & $148.9 \mathrm{~b}$ & $6.3 \mathrm{~b}$ & 9.9 b & $45.3 b$ & $45.5 \mathrm{a}$ \\
\hline
\end{tabular}

n.s. Not significant at the 0.05 and 0.01 probability levels.

Highly significant differences among wheat genotypes in grain yield were observed, while the interaction between wheat genotypes and systems was insignificant. The Egyptian genotypes ('Sids 12 ' and Early-line) and Yocora Rojo showed the highest grain yield $\left(6.0,6.4\right.$ and 6.1 tons ha ${ }^{-1}$, respectively), while the lowest grain yield was obtained for the local genotype (4.1 tons $\mathrm{ha}^{-1}$ ). The Egyptian genotypes (Sids 12 ' and Early line) produced the highest grain yields under the conventional system (Fig. 1). In the organic system, Yocora Rojo and Early-line produced the highest grain yields (Fig. 1). Grain and straw yields were higher during the growing seasons (2011 and 2012) versus the 2010 growing season. This finding may be due to suitable cold weather conditions during the 2011 and 2012 growing seasons, which led to increased GFR, and is reflected in the total yields (Table 4). Significant differences were found in straw yield between the conventional and organic systems and among wheat genotypes. The straw yield of organically grown wheat was $14.6 \%$ lower than that of conventionally grown wheat (Table 4). Straw yields were highest in the local genotypes (12.2 tons $\mathrm{h}^{-1}$ ) (Table 4$)$.

\section{Grain filling period}

Data of grain filling period (GFP) showed that there were a significant differences $(P<0.01)$ between conventional and organic system (Table 4). A variation between wheat genotypes in the GFP was observed (Table 4). The Egyptian genotypes (Early-line and 'Sids 12' ) and Yocora Rojo (44.89, 43.61 and 43.89 days) had the grater GFP while the lowest was IC8, IC17 and local genotypes (36.83, 36.78 and 35.44 days), respectively (Table 4 and Fig. 2). The growing seasons (2011 and 2012) showed a greater GFP over the growing season 2010 (Table 4). 


\section{Grain-filling rate}

There were significant differences in the GFR $(P<0.01)$ between the conventional and organic systems (Table 4). The second and third growing seasons showed a greater GFR than the first growing season. As indicated previously, suitable cold and dry weather conditions during the 2011 and 2012 growing seasons facilitated the increase in the GFR. Variation was observed among wheat genotypes (Table 4). The ICARDA genotypes (IC8 and IC17) and Early-line had the greatest GFR $\left(165.6,167.2\right.$ and $153.4 \mathrm{~kg} \mathrm{ha}^{-1} \mathrm{~d}^{1}$, respectively), whereas the lowest GFRs were found in the Australian genotypes (P5 and P3) and the local genotype (Table 4). It should be noted that Early-line and ICARDA genotypes (IC8 and IC17) had the greatest GFR in both systems, while Egyptian genotype "Sids12" had the greatest GFR in the conventional system and the lowest GFR in organic system (Fig. 3).

\section{Days to heading and days to maturity}

The organic system had a longer time to heading than the conventional system by approximately $6 \%$ (Table 4$)$. There were significant differences $(P<0.01)$ in DTH between the two agriculture systems and among wheat genotypes (Table 4). However, there were insignificant differences in days to maturity (DTM) between the conventional and organic systems. The second and third growing seasons showed a longer time to heading and maturity than the first growing season (Table 4). Early-line had the lowest DTH and DTM (67.1 and 112 days, respectively), yet it produced the highest grain yield in both systems, whereas the highest DTH and DTM were found in the local genotype (91.4 and 126.6 days, respectively) (Table 4).

\section{Number of kernels spike ${ }^{-1}$ and 1000-kernel weight}

There were insignificant differences in number of kernel spike $^{-1}$ between the conventional and organic systems. The ICARDA genotypes (IC8 andIC17) and Egyptian genotype (Sids 12) had greater kernels spike ${ }^{-1}(54.3,54.1$ and 59.5, respectively) (Table 4). The 1000-kernel weight data showed significant differences between the agriculture systems (Table 4), and the wheat genotypes Yocora Rojo, Early-line, and Sids 12 had the greatest 1000-kernel weight under both systems. The second and third growing seasons showed a greater 1000-kernel weight than the first growing season.

\section{Discussion}

The results obtained in this study showed significant differences in grain yield between the organic and conventional systems. These findings are important because most wheat production lands in Saudi Arabia have low soil fertility. These findings are consistent with those of Ryan et al. (2004) and Stanhill (1990), who found a significant yield decrease under organic versus conventional systems. A yield reduction between the organic and conventional systems confirmed the results reported for wheat in other field experiments, where differences have been identified depending on management system used (Quaranta et al., 2010; Stagnari et al., 2013). Also, lannucci and Codianni (2016) reported that wheat yield for the organic system was $40 \%$ lower than that of the conventional system. In addition, wheat genotypes varied for all agronomic traits in both systems.

Based on our results, the Egyption genotype 'Early-line' showed good seed yield under both systems. Therefore, this genotype can be recommended for low soil fertility (lannucci and Codianni, 2016). Iannucci and Codianni (2016) proved that the most popular cultivars of durum wheat used for conventional farming are also suitable for organic farming in the Mediterranean environments. However, other studies (Murphy et al., 2007; Lammerts van Bueren et al., 2011) reported that the highest yielding wheat genotypes in conventional systems are not the highest yielding genotypes in organic systems.

Our results showed significant differences among the eight genotypes in the GFR. It should be noted that the Early-line genotype had the greatest GFR and the lowest DTH and DTM in the organic system. Liatukas and Leistrumaite (2009) found that early-heading and -maturing cultivars have higher flour yield than later-ripening cultivars in organic systems. Therefore, for the organic system, wheat yield had negative correlation with heading time (lannucci and Codianni, 2016). In addition, the present study showed that wheat genotypes (IC8, IC17 and Sids 12) had the greatest number of kernels spike ${ }^{-1}$ in both systems. Wolfe et al. (2008) reported that the number of tillers was not correlated with organic or conventional systems. Gevrekk and Atasoy (2012) suggested that wheat yield reduction in organic systems was primarily due to reduced kernel number per spike ${ }^{-1}$ and 1000-kernel weight.

The data obtained in this study revealed significant differences in grain yield between the 2010, 2011 and 2012 growing seasons, which is most likely due to the relatively colder growing seasons in 2011 and 2012. Relatively warm temperatures in the 2010 growing season would cause yield reductions, as there are reductions in grain development due to high temperatures during the grain-filling period. Increased temperatures might also cause abnormal development and shorten the grain-filling period (Stone and Nicolas 1994). lannucci and Codianni (2016) have shown that within each cropping system, the major differences in seed yield among the years were associated with the temperatures.

\section{Materials and methods}

\section{Site description}

Organic and conventional trials were conducted during the 2010 and 2011 growing seasons at two different locations. Additional trial was conducted for both organic and conventional systems in 2012 at Qassim University Agricultural Research Station.

The conventional trial was established at Qassim University Agricultural Research Station $\left(26^{\circ} 18^{\prime} 28^{\prime \prime} \mathrm{N}, 43^{\circ} 46^{\prime} \mathrm{E}\right)$. This trial was treated according to standard agriculture applications, including the use of chemical fertilizers as recommended by soil test results. The organic trial was established at a certified organic farm that belongs to the Research Center for Organic Agriculture at the Ministry of Environment, Water and Agriculture $\left(26^{\circ} 18^{\prime} 28^{\prime \prime} \mathrm{N}, 44^{\circ} 46^{\prime} \mathrm{E}\right)$. The organic trial was treated according to the organic system regulations set by the Ministry of Environment, Water and Agriculture in Saudi Arabia. Soil chemical and physical characteristics of the two experiment sites are listed 
in Table 1. The maximum and minimum air temperatures during 2010, 2011, and 2012 growing seasons (Jan to April) are presented in Table 2.

\section{Plant material}

Eight bread wheat genotypes (Table 3) were used as plant materials for both conventional and organic conditions. The experiment was a randomized complete block design (RCBD) with four replications using $3-\mathrm{m}^{2}$ plots $(1.5 \mathrm{~m} \times 2 \mathrm{~m}$ ) (ten rows per plot) with seeding rate of $45 \mathrm{~kg} \mathrm{ha}^{-1}$. Seeding dates were performed on December 6 and 7, 2009, and December 6 and 5, 2010 for organic and conventional systems in each year, respectively. In 2012 season, the seeding date for both systems was performed on December 5, 2011. Nitrogen (N) was applied to all conventional plots in the form of Diammonium Phosphate (DIP) (18-46-0) at a rate of $180 \mathrm{~kg}$ $\mathrm{ha}^{-1,}$ and Urea (46-0-0) at the rate of $200 \mathrm{~kg} \mathrm{ha}^{-1}$. Organic trails had two years crop rotation with alfalfa (Medicago Sativa). Organic fertilizer in the form of cow manure was applied at a rate of 10 tons ha ${ }^{-1}$, usually a month prior to the seeding date. All plots were irrigated equally using sprinkler irrigation system. No pesticides were used to control pests or diseases for both systems.

\section{Data collection}

In each system, earliness characteristics were measured, including days to heading (DTH), days to maturity (DTM), grain filling period (GFP), and grain-filling rate (GFR; $\mathrm{kg} \mathrm{ha}^{-1}$ $\mathrm{day}^{-1}$ ). Yield components were determined by measuring the number of kernels spike ${ }^{-1}$ and the 1000 -kernel weight. Grain and straw yields were obtained from the four central rows to eliminate the border effect of each plot and then converted into tons $\mathrm{ha}^{-1}$.

\section{Statistical analyses}

Analysis of variance (ANOVA) was carried out using JMP Ver. 11 (SAS Institute, 2013) to compare means of the organic and conventional systems, wheat genotypes, and years for all variables. A linear mixed model was used, in which wheat genotypes and systems factors were regarded as fixed factors, while year was regarded as a random factor. Treatment means were separated by Duncan's multiple range tests at $P<0.05$.

\section{Conclusion}

This study demonstrated variation between conventional and organic systems in grain yield, straw yield, DTH, and DTM. The overall results indicated that there is genetic variability present in the materials studied. The genotypes Early-line and Yocora Rojo had the highest grain yield and the greatest GFR under the organic system, whereas the lowest grain yields and GFRs were obtained in the local genotype and the Australian genotypes (P5 and P3). Earlyline had the lowest DTH and DTM under both systems. Therefore, these data clearly indicate that Early-line and Yocora Rojo are well adapted to organic production systems in low-fertility soil.

Acknowledgments
The authors gratefully acknowledge the Dean of Scientific Research at Qassim University for funding this project. We thank the research crew at the Research Center for Organic Agriculture for their technical support and help in managing the plots. Our appreciation is extended to Prof. M.M. Fathi for his assistance with the statistical analyses and Dr. AbdelSalam Menshawy for collecting the data.

\section{References}

Al-Ghumaiz NS (2014) Yield performance quality of eight wheat genotypes under organic and conventional farming systems in Saudi Arabia. Agriculture and Food. Volume 2:pp20-24. [Online] Available: http://www.scientificpublications.net/en/article/1000002/

Carr PM, Kandel HJ, Porter PM, Horsley RD, Zwinger SF (2006) Wheat cultivar performance on certified organic fields in Minnesota and North Dakota. Crop Sci. 46: 19631971.

Gevrekk MN, Atasoy GD (2012) Performance of some bread wheat genotypes under organic and conventional production systems. Int J Agric Biol. 14: 580-584.

lannucci A, Codianni P (2016) Effects of conventional and organic farming systems on bio-agronomic and quality traits of durum wheat under Mediterranean conditions. Aust J Crop Sci. 10(8):1083-1091.

Lammerts van Bueren ET, Jones SS, Tamm L, Murphy KM, Myers JR, Leifert C, Messmer MM (2011) The need to breed crop varieties suitable for organic farming, using wheat, tomato and broccoli as examples: a review. NJAS_Wageningen J Life Sci. 58: 193- 205.

Liatukas Ž, Leistrumaitė A (2009) Selection of winter wheat for organic growing. Agron Res. 7: 381-386.

Mäder P, Hahn D, Dubois D, Gunst L, Alföldi T, Bergmann H, Oehme M, Amadò R, Schneider $H$, Graf $U$, Velimirov $A$, Fließbach A, Niggli U (2007) Wheat quality in organic and conventional farming: results of a 21 year field experiment. J Sci Food Agric. 87: 1826-1835.

Mason HE, Navabi A, Frick BL, O'Donovan JT, Spaner DM (2007) The weed-competitive ability of Canada western red spring wheat cultivars grown under organic management. Crop Sci. 47: 1167-1176.

Ministry of Environment, Water and Agriculture (2015) Agriculture statistical year book, Saudi Arabia.

Murphy KM, Campbell KG, Lyon SR, Jones SS (2007) Evidence of varietal adaptation to organic farming systems. Field Crops Res. 102: 172-177.

Nass HG, Ivany JA, MacLeod J.A (2003) Agronomic performance and quality of spring wheat and soybean cultivars under organic culture. Am J Altern Agric. 18: 164170.

Nelson AG, Quideau S, Frick B, Niziol D, Clapperton J, Spaner D (2011) Spring wheat genotypes differentially alter soil microbial communities and wheat bread making quality in organic and conventional systems. Can J Plant Sci. 91: 485495.

Quaranta F, Amoriello T, Aureli G, Belocchi A, Bentivenga G, D'Egidio MG, Melloni S, Camerini M (2010) Grain yield, quality and deoxinyvalenol (DON) contamination of durum wheat (Triticum durum Desf.): results of national networks in organic and conventional cropping systems. Ital J Agron. 5: 361-374. 
Ryan M, Derrick J, Dann P (2004) Grain mineral concentrations and yield of wheat grown under organic and conventional management. J Sci Food Agric. 84: 207216.

SAS Institute (2013) JMP Version 11. User's Guide, SAS Institute Inc., Cary, NC.

Stagnari F, Onofri A, Codianni P, Pisante M (2013) Durum wheat varieties in $\mathrm{N}$-deficient environments and organic farming: a comparison of yield, quality and stability performances. Plant Breed. 132: 266-275.
Stanhill G (1990) The comparative productivity of organic agriculture. Agric Ecosyst Environ. 30: 1-26.

Stone P, Nicolas M (1994) Wheat cultivars vary widely in their responses of grain yield and quality to short periods of post-anthesis heat stress. Aust J Plant Physio. 21: 887900.

Wolfe MS, Baresel JP, Desclaux D, Goldringer I, Hoad S, Kovacs G, Löschenberger $F$, Miedaner $T$, $\emptyset$ stergård $H$, Lammerts van Bueren ET (2008) Developments in breeding cereals for organic agriculture. Euphytica. 163: 323-346. 